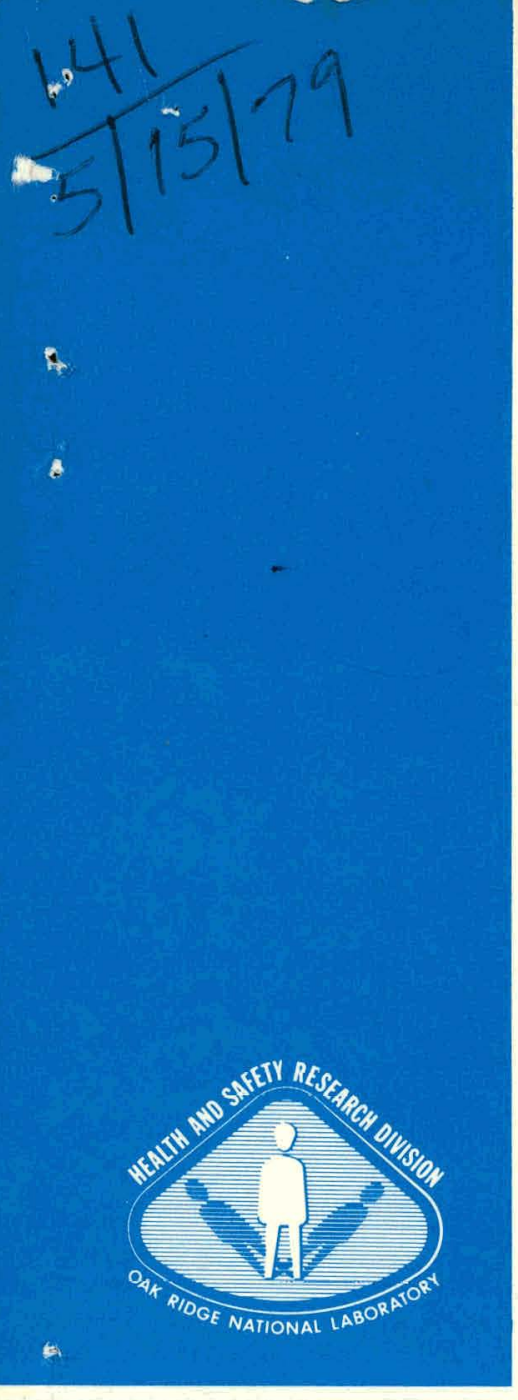

\title{
Conversion of Tritium Gas to Tritiated Water
}
P. J. Papagiannakopoulos
C. E. Easterly 


\section{DISCLAIMER}

This report was prepared as an account of work sponsored by an agency of the United States Government. Neither the United States Government nor any agency Thereof, nor any of their employees, makes any warranty, express or implied, or assumes any legal liability or responsibility for the accuracy, completeness, or usefulness of any information, apparatus, product, or process disclosed, or represents that its use would not infringe privately owned rights. Reference herein to any specific commercial product, process, or service by trade name, trademark, manufacturer, or otherwise does not necessarily constitute or imply its endorsement, recommendation, or favoring by the United States Government or any agency thereof. The views and opinions of authors expressed herein do not necessarily state or reflect those of the United States Government or any agency thereof. 


\section{DISCLAIMER}

Portions of this document may be illegible in electronic image products. Images are produced from the best available original document. 


\section{Printed in the United States of America. Available from National Technical Information Service U.S. Department of Commerce 5285 Port Royal Road, Springfield, Virginia 22161 \\ Price: Printed Copy $\$ 4.50$; Microfiche $\$ 3.00$}

This report was prepared as an account of work sponsored by an agency of the United States Government. Neither the United States Government nor any agency thereof, nor any of their employees, contractors, subcontractors, or their employees, makes any warranty, express or implied, nor assumes any legal liability or responsibility for any third party's use or the results of such use of any information, apparatus, product or process disclosed in this report, nor represents that its use by such third party would not infringe privately owned rights. 
ORNL/TM-6699

Dist. Category UC-20, -20 e

Contract No. W-7405-eng-26

\begin{abstract}
Health and Safety Resenrch Division
Fusion Technology Studies
\end{abstract}

\title{
CONVERSION OF TRITIUM GAS TO TRITIATED WATER
}

P. J. Papagiannakopoulos* and C. E. Easterly

*Postdoctoral Fellow, University of Tennessee, Knoxville, Tennessee

Date Published: May 1979

NOTICE This document contains information of a preliminary nature. It is subject to revision or correction and therefore does not represent a final report.

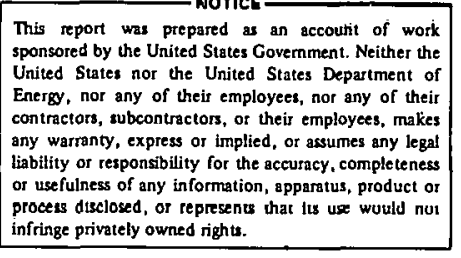

infringe privately owned rights.

OAK RIDGE NATIONAL LABORATORY

Oak Ridge, Tennessee 37830

operated by

UNION CARBIDE CORPORATION

for the

DEPARTMENT OF ENERGY 
THIS PAGE

WAS INTENTIONALLY

LEFT BLANK 
TABLE OF CONTENTS

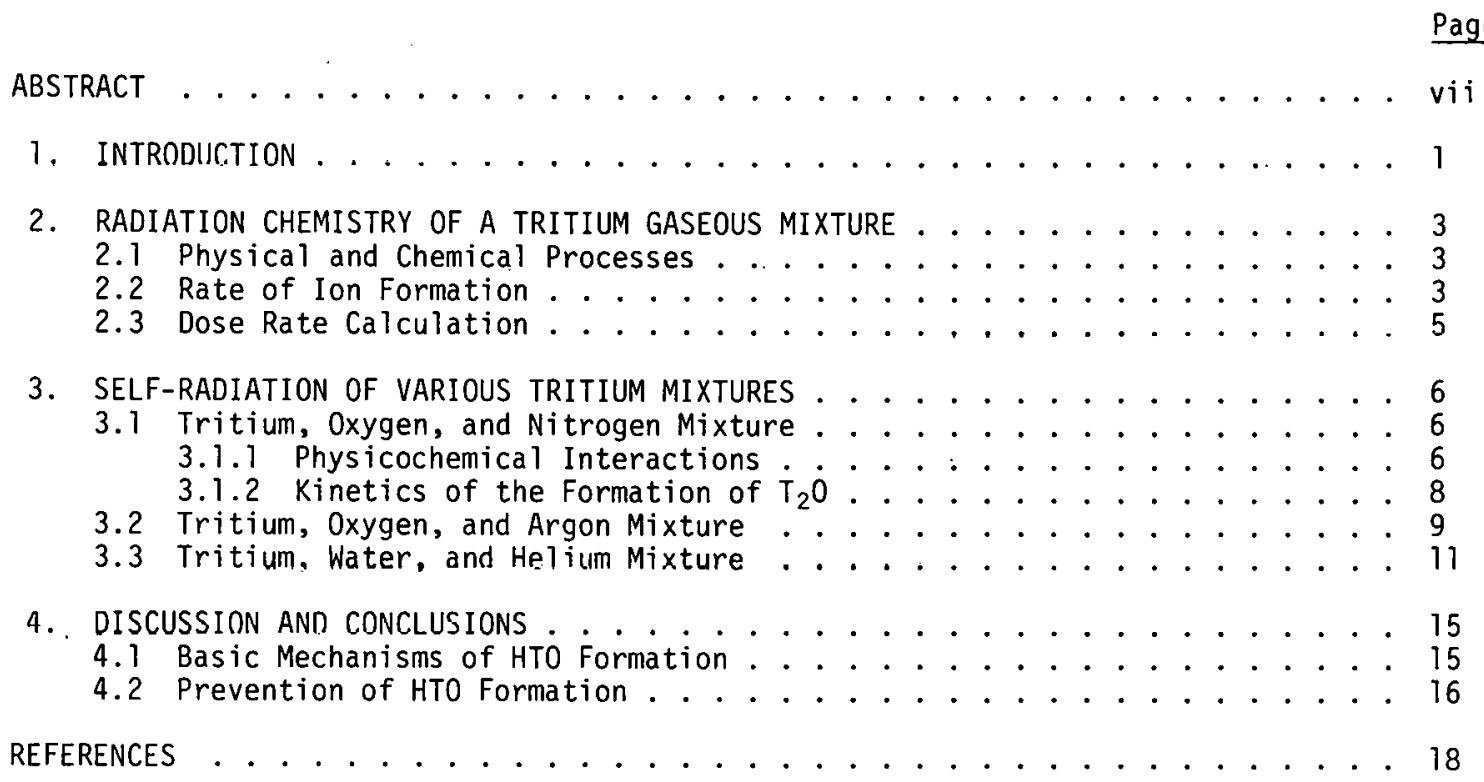




\section{THIS PAGE}

WAS INTENTIONALLY

LEFT BLANK 


\section{LIST OF TABLES}

$\underline{\text { Tables }}$

1 The conversion of tritium to HTO in various gas mixtures ........ 2

2 Absorption coefficients for trittum beta particles ...........4

3 Calculated and experimental rates of HTO formation . . . . . . . . . 10 
THIS PAGE

\section{WAS INTENTIONALLY \\ LEFT BLANK}




\title{
CONVERSION OF TRITIUM GAS TO TRITIATED WATER
}

P. J. Papagiannakopoulos and C. E. Easterly

\begin{abstract}
The mechanisms of conversion of tritium gas to tritiated water (HTO) have been examined for several tritium gaseous mixtures. The physical and chemical processes involved in the self-radiolysis of such mixtures have been analyzed and the kinetics involved in the formation of HTO has been presented. It has been determined that the formation of the $\mathrm{H}$ and/or $\mathrm{OH}$ free radicals, as intermediate species, are of significance in the formation of HTO. Therefore, the problem of reducing the rate of formation of tritiated water in a mixture of gaseous tritium with atmospheric components is one of finding an effective scavenger for the $\mathrm{H}$ and/or $\mathrm{OH}$ free radicals.
\end{abstract}




\section{INTRODUCTION}

During the normal operation of a fusion reactor, small amounts of tritium will be lost to areas occupied by operational personnel and to the external environment. Gaseous tritium (HT) will interact with various atmospheric components and may form tritiated water vapor (HTO), which is substantially more hazardous to man than tritium gas. A knowledge of the formation rate of HTO is important in order to perform an analysis of health effects. Further, an, understanding of the formation mechanism is necessary in order to develop appropriate methods to reduce the conversion rate of HT to HTO and, hence, to reduce the potential occupational risk within an enclosed area. Therefore, a study of the detailed mechanisms of the conversion of $T_{2}$ (HT) to HTO is appropriate.

Conversion of tritium to tritiated water has been explained in the past through oxidation and isotopic exchange mechanisms. Oxidation proceeds through the reaction

$$
\mathrm{T}_{2}+1 / 2 \mathrm{O}_{2} \rightarrow \mathrm{T}_{2} \mathrm{O}
$$

and the isotopic exchange mechanism proceeds through the reaction

$$
\mathrm{T}_{2}+\mathrm{H}_{2} \mathrm{O} \rightarrow \mathrm{HTO}+\mathrm{HT}
$$

The oxidation mechanism was introduced by Dorfman and Hemmer ${ }^{1}$ in a study of the reaction between tritium and oxygen, initiated by the tritium beta radiation, at $25^{\circ} \mathrm{C}$. The tritium pressure was in the range of 30-104 mm; the oxygen pressure was in the range of 69-218 mm, and there was a molar fraction of protium in the hydrogen reactant in the range of $0.055-0.831$. The initial reaction rate $d[H T O] / d t$ was found to be proportional to the concentration of $\left[T_{2}\right]$, and was given' by the equation

$$
\frac{\mathrm{d}[\mathrm{HTO}]}{\mathrm{dt}}=\mathrm{k}\left[\mathrm{T}_{2}\right]\left(1+b \mathrm{~m}_{\mathrm{H}}\right)
$$

where $k=1.98 \times 10^{-6} \mathrm{sec}^{-1}$ is the rate constant of the reaction, $b=0.3$ is the isotope effect correction, and $m_{H}$ is the molar fraction of protium in the hydrogen reactant. Therefore, over the range of initial conditions, the reaction is of the first order and independent of the oxygen concentration.

The isotopic exchange mechanism was introduced by Yang and Gevantman ${ }^{2}$ in a study of self-radiation of a mixture of tritium gas and water vapor, in an atmosphere of helium, at $22 \pm 2{ }^{\circ} \mathrm{C}$. The tritium pressure was in the range of $0.0159-0.2225 \mathrm{~mm}$, the water vapor density was 5-17.5 mg liter-1, and the helium pressure was in the range of 564-627 mm. The initial rate $\mathrm{d}[\mathrm{HTO}] / \mathrm{dt}$ was described ${ }^{2}$ by the equation

$$
\frac{d[H T O]}{d t}=k\left[T_{2}\right]^{2}
$$


where $\mathrm{k}=4.17 \times 10^{-7}$ liter $\mathrm{Ci}^{-1} \mathrm{sec}^{-1}$ is the rate constant of the reaction. Therefore, the reaction is taken to be second order and independent of water vapor concentration.

The above two mechanisms have also been employed by other workers ${ }^{3-5}$ for the explanation of their experimental results obtained under varying tritium concentrations and different gas mixtures. The tritium mixtures examined in the past and experimentally observed rates of HTO formation are presented in Table 1 . From the literature examined, it is apparent that the mechanism(s) of conversion of tritium gas to tritiated water depend on (a) the composition of the gas mixture, (b) the concentration of each gas component, (c) the temperature, and (d) the presence of catalysts. 6

In order to probe further the mechanism(s) of conversion of tritium gas to tritiated water, it is necessary first to examine the various physical and chemical processes that are involved in a gas mixture of tritium. These processes must bc applied to different known gaseous mixtures to explain the experimental results. Once these physical and chemical processes are understood, appropriate methods for the elimination or reduction of the conversion of $\mathrm{T}_{2}$ to HTO can be examined.

Table 1. The conversion of tritium to HTO in various gas mixtures

\begin{tabular}{|c|c|c|c|}
\hline Mixture & $\begin{array}{c}\mathrm{T}_{2} \text { Concentration } \\
\left(\mathrm{Ci} \text { liter }^{-1}\right)\end{array}$ & $\begin{array}{c}\text { Conversion rate } \\
\text { d[HTO]/dt } \\
\text { (Ci liter } \text { sec }^{-1} \text { ) }\end{array}$ & Reference \\
\hline $\mathrm{T}_{2}+\mathrm{H}_{2}+\mathrm{O}_{2}$ & $95-328$ & $1.98 \times 10^{-6}\left[T_{2}\right]$ & $a$ \\
\hline$T_{2}+O_{2}+A r$ & $0.09-90$ & $1.7 \times 10^{-8}\left[\mathrm{~T}_{2}\right]^{5 / 3}$ & $b$ \\
\hline$T_{2}+O_{2}+N_{2}$ & $0.018-1$ & $3.30 \times 10^{-7}\left[\mathrm{~T}_{2}\right]^{2}$ & o \\
\hline $\mathrm{T}_{2}+\mathrm{O}_{2}+\mathrm{H}_{2} \mathrm{O}$. & $\therefore 1$ & $1.20 \times 10^{-5}\left[T_{2}\right]^{2}$ & $c$ \\
\hline$T_{2}+$ Dry Air & $0.015-0.8$ & $1.7 \times 10^{-7}\left[\mathrm{~T}_{2}\right]^{2}$ & $c$ \\
\hline $\mathrm{T}_{2}+\mathrm{H}_{2} \mathrm{O}+\mathrm{He}, \mathrm{N}_{2}, \mathrm{Ar}, \mathrm{Kr}$ & $0.05-0.7$ & $4.2 \times 10^{-7}\left[T_{2}\right]^{2}$ & $d$ \\
\hline $\mathrm{T}_{2}+\mathrm{H}_{2} \mathrm{O}+$ Dry Air & $6 \times 10^{-4}-600$ & $1.7 \times 10^{-8}\left[T_{2}\right]^{5 / 3}$ & $b$ \\
\hline
\end{tabular}

$a_{L}$. M. Dorfman and B. A. Hemmer, J. Chem. Phys., 22, 1555 (1954).

$b_{L}$. F. Belovodskii, V. K. Gaevoi, V. I. Grishmanovski1, and N. V. Nefedov, At. Energ., 38, 379 (1975).

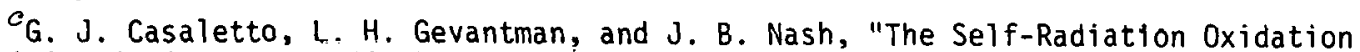
of Tritium in 0xygen and Air," USNRDL-TR-565, Naval Radiol. Def. l.ah., San Francisco, Calif., 1962.

dJ. Yang and L. H. Gevantman, J. Phys. Chem., 68, 3115 (1964). 


\section{RADIATION CHEMISTRY OF A TRITIUM GASEOUS MIXTURE}

\subsection{Physical and Chemical Processes}

In a tritium gaseous mixture, the conversion of tritium gas to tritiated water occurs through a number of physical and chemical processes. The tritium molecules of the mixture decay by emitting beta particles (electrons) with an average energy of $5.7 \mathrm{keV}$, and a maximum energy of $18.6 \mathrm{keV} .{ }^{7}$ These beta particles have an initial kinetic energy much higher than the mean kinetic energy of molecules in the mixture. Therefore, they lose energy through collisions with the mixture molecules until they become thermalized and eventually disappear by recombination with positive ions or by attachment to neutral molecules. The molecules of the mixture absorb some of the beta-particle energy and undergo ionization or excitation, depending on the amount of energy transferred; this results in the formation of positive ions and excited molecules. The relative amounts of ionization and excitation depend on the energy of the primary electrons. ${ }^{8}$ A primary electron with an average energy of $5.7 \mathrm{keV}$ when fully absorbed by the mixture produces approximately 170-190 ions, depending on the W-value 9 (ionization efficiency) of the mixture.

The positive ions collide with neutral molecules and undergo charge transfer or ion-molecule reactions. 10 A charge-transfer process preserves the chemical identity of the reactants, whereas an ion-molecule reaction does not. For a charge-transfer process to occur, the ionization potential of the neutral molecule must be lower than that of the positive ion. Neutralization of the positive ions through the processes of recombination with a thermal electron or a negative ion is not probable at atmospheric pressures and room temperatures. The fate of the excited molecules is mainly to decompose and form free radicals, and if the excitation energy is high enough, the free radicals may be in excited states.

The above processes result in the formation of free radicals which then induce a number of radical reactions. These radical reactions are responsible for the formation of the final products, in this case, the formation of tritiated water.

In the presence of high concentrations of water vapor, ion clusters ${ }^{11}$ are produced by the interaction of positive ions and water molecules. The fate of the ions in the cluster is not known and is open to question.

\subsection{Rate of Ion Formation}

In a tritium gas mixture the rate of ion formation can be calculated from the tritium concentration and the fraction of the decay-product energy absorbed by the mixture.12

The disintegration of $\mathrm{n}_{\mathrm{T}_{2}}$ moles of $\mathrm{T}_{2}$ results in the formation of $1.78 \times 10^{-9} \mathrm{n}_{\mathrm{T}_{2}}$ electrons $\sec ^{-1}$. The decay electron, with an average energy of $5.7 \times 10^{3} \mathrm{eV}$, forms $5.7 \times 10^{3} / \mathrm{W}$ ion pairs. Therefore, the rate of decomposition of $n_{A}$ moles of gas $A$ to ion pairs will be

$$
-\frac{d n_{A}}{d t}=1.78 \times 10^{-9} \times\left(5.7 \times 10^{3} / \mathrm{W}\right) n_{T_{2}} \times F f_{A} \text {, }
$$


where $F$ is the fraction of energy absorbed in the gas phase (not by the container walls in an experiment) and $f_{A}$ is the fraction of $F$ which is absorbed by gas $A$. For a gas mixture, $f_{A}=\mu_{A} \nu_{A} / \bar{\mu}$, where $\mu_{A}$ is the linear absorption coefficient of gas $A$ for tritium beta particles, $v_{A}$ is the mole fraction of gas $A$ in the mixture, and $\bar{u}$ is the average linear absorption coefficient of the gas'mixture given by $\bar{\mu}=\Sigma \mu_{j} \nu_{i}$. Calculation of the above quantities for various gas mixtures has been done by Mueller. ${ }^{13}$

The linear absorption coefficients of various gases for tritium beta particles at $25^{\circ} \mathrm{C}$ and $760 \mathrm{~mm}$ are presented in Table 2. Linear absorption coefficients at other temperatures and pressures can be found by multiplying the values given in Table 2 by the ratio of the density at the given conditions to the density at $25^{\circ} \mathrm{C}$ and $760 \mathrm{~mm}$. Substituting the expression for $f_{A}$ and dividing by $n_{A}$ eq. (2.1) becomes

$$
-\frac{d n_{A}}{n_{A}}=1.78 \times 10^{-9}\left(5.7 \times 10^{3} / W\right) n_{T_{2}} \frac{F}{n_{A}} \stackrel{{ }_{\bar{\mu}}{ }^{v} A}{{ }^{\nu}} d t .
$$

or, using the ideal gas law,

$$
-\frac{\mathrm{d}[\mathrm{A}]}{[\mathrm{A}]}=1.78 \times 10^{-9}\left(5.7 \times 10^{3} / \mathrm{W}\right)\left(\frac{\mathrm{RT}}{\mathrm{A}}\right) \frac{\left[\mathrm{T}_{2}\right]}{\mathrm{P}_{\text {tot }}} \mathrm{F} \frac{\mu_{\mathrm{A}}}{\bar{\mu}} \mathrm{dt} \text {, }
$$

where $P_{\text {tot }}$ is the total pressure, $R$ is the ideal gas constant, $T$ is the absolute temperature, and $A$ is Avogadro's constant. At the initial stages of the reaction, the fraction $\left[T_{2}\right] / P$ tot is essentially constant; therefore, at constant temperature the expression

$$
k_{A}=1.78 \times 10^{-9}\left(5.7 \times 10^{3} / W\right)\left(\frac{R T}{A}\right) \frac{\left[T_{2}\right]}{P_{\text {tot }}} F \frac{\mu_{A}}{\bar{\mu}},
$$

can be considered as constant.

Table 2. Absorption coefficients for tritium beta particles ${ }^{a}$

\begin{tabular}{cc}
\hline Gas & $\begin{array}{c}\text { Ahsorptinn coefficient } \\
\mu\left(\mathrm{cm}^{-1}\right)\end{array}$ \\
\hline $\mathrm{H}_{2}$ & 1.81 \\
$\mathrm{He}$ & 1.68 \\
$\mathrm{~N}_{2}$ & 11.0 \\
$\dot{U}_{2}$ & 12.4 \\
$\mathrm{Ne}$ & 7.59 \\
$\mathrm{Ar}$ & 12.9 \\
$\mathrm{Kr}$ & 23.4 \\
$\mathrm{Xe}$ & 33.4 \\
$\mathrm{Air}$ & 11.3 \\
$\mathrm{H}_{2} \mathrm{O}$ & 8.0
\end{tabular}

October 10, 1967 . 
Hence, the equation

$$
-\frac{d[A]}{d t}=k_{A}[A]
$$

is obtained which gives the initial rate of decomposition of A molecules to ion pairs.

\subsection{Dose Rate Calculation}

For a tritium gaseous mixture in which the concentration of tritium is much smaller than the concentration of the other mixture components, the dose absorbed by the mixture will be approximately equal to the total energy liberated by the disintegrating nuclei. In a mixture with a tritium concentration of $C$ millicuries per gram (equivalent to $3.7 \times 10^{7} \mathrm{C}$ dis/g.sec), the absorbed dose rate will he

$$
\begin{aligned}
\dot{D}= & 3.7 \times 10^{7} \mathrm{C}\left(\frac{\mathrm{dis}}{\mathrm{g} \cdot \mathrm{sec}}\right) \times \bar{E}\left(\frac{\mathrm{MeV}}{\mathrm{dis}}\right) \times 1.602 \times 10^{-8}\left(\frac{\mathrm{g} \cdot \mathrm{rad}}{\mathrm{MeV}}\right)=0.593 \times \mathrm{C} \times \bar{E} \mathrm{rad} \mathrm{sec}^{-1} \\
= & 3.38 \times 10^{-3} \times \mathrm{C} \mathrm{rad} \mathrm{sec}-1
\end{aligned}
$$

where $\bar{E}=5.7 \times 10^{-3} \mathrm{MeV}$ is the average energy released by tritium disintegration and transferred to the primary electrons. 14 The total absorbed dose is given by the product of the above dose rate and the period of irradiation. 


\section{SELF-RADIATION OF VARIOUS TRITIUM MIXTURES}

The rate of conversion of tritium to tritiated water has been evaluated in the past by performing experiments on mixtures with various compositions (Table 1). An understanding of the conversion mechanism of tritium gas to tritiated water can be reached by analyzing these experimental results in light of the radiation chemistry involved in a mixture of tritium with other gases.

\subsection{Tritium, 0xygen, and. Nitrogen Mixture}

\subsubsection{Physicochemical interactions}

Experiments with mixtures of tritium, oxygen, and nitrogen were performed by Casaletto et al. ${ }^{3}$ In these experiments, the main component gas was nitrogen, and the total pressure of the mixture was $700 \mathrm{~mm}$. Irradiation of such a mixture results in the formation of $\mathrm{N}_{2}^{+}, \mathrm{O}_{2}{ }^{+}$, and $\mathrm{T}_{2}^{+}$positive ions and $\mathrm{N}_{2}{ }^{*}, \mathrm{O}_{2}{ }^{*}$, and $\mathrm{T}_{2}{ }^{*}$ excited molecules. The ionic and excitation processes are

$$
\begin{aligned}
\mathrm{N}_{2}+\mathrm{e} & \rightarrow \mathrm{N}_{2}^{+}+2 \mathrm{e}, \\
& \rightarrow \mathrm{N}_{2}^{*}+\mathrm{e}, \\
\mathrm{O}_{2}+\mathrm{e} & \rightarrow \mathrm{O}_{2}^{+}+2 \mathrm{e}, \\
& \rightarrow \mathrm{O}_{2}^{*}+\mathrm{e}, \\
\mathrm{T}_{2}+\mathrm{e} & \rightarrow \mathrm{T}_{2}^{+}+2 \mathrm{e}, \\
& \rightarrow \mathrm{T}_{2}^{\star}+\mathrm{e} .
\end{aligned}
$$

The $\mathrm{N}_{2}^{+}$ions are the main positive ions in the mixture and probably undergo the reactions: 15,16

$$
\begin{aligned}
& \stackrel{+}{\mathrm{N}_{2}}+\mathrm{O}_{2} \stackrel{\mathrm{k}_{1}}{\longrightarrow} \mathrm{O}_{2}^{+}+\mathrm{N}_{2}, \quad \mathrm{k}_{1}=5 \times 10^{-11} \mathrm{~cm}^{3} \text { molecule } \\
& \mathrm{N}_{2}^{+}+\mathrm{T}_{2} \stackrel{\mathrm{k}_{2}}{\longrightarrow} \mathrm{sec}_{2} \mathrm{~T}^{+}+\mathrm{T}, \quad \mathrm{k}_{2}=2.1 \times 10^{-9} \mathrm{~cm}^{3} \text { molecule }
\end{aligned}
$$

The reaction (3.1) is predominant, especially for higher oxygen concentration. The $0_{2}^{+}$ions undergo the reaction ${ }^{17}$

$$
0_{2}^{+}+20_{2} \rightarrow 0_{4}^{+}+0_{2}, k_{3}=2.6 \times 10^{-30} \mathrm{~cm}^{6} \text { molecule } \mathrm{e}^{-2} \varepsilon^{-1}
$$

Reaction (3.2) results in the formation of $\mathrm{N}_{2} \mathrm{~T}^{+}$ions and tritium atoms. The tritium atoms induce a number of free radical reactions ${ }^{18}$ of which the most important are: 


$$
\begin{aligned}
& \mathrm{T}+\mathrm{O}_{2}+\mathrm{T}_{2} \longrightarrow \mathrm{TO}_{2}+\mathrm{T}_{2}, \mathrm{k}_{4}=4.0 \times 10^{-32} \mathrm{~cm}^{6} \text { molecule } \text { mo }^{-2} \mathrm{sec}^{-1} \text {; } \\
& \mathrm{T}+\mathrm{TO}_{2} \rightarrow \mathrm{T}_{2}+\mathrm{O}_{2}, \mathrm{k}_{5}=1.3 \times 10^{-11} \mathrm{~cm}^{3} \text { molecule } \mathrm{e}^{-1} \mathrm{sec}^{-1} \text {; } \\
& \longrightarrow 0 \mathrm{OT}+\mathrm{OT}, \mathrm{k}_{6}=1.7 \times 10^{-11} \mathrm{~cm}^{3} \text { molecule }-1 \mathrm{sec}^{-1} \text {; } \\
& \longrightarrow \mathrm{T}_{2} \mathrm{O}+0, \mathrm{k}_{7}=1.6 \times 10^{-11} \mathrm{~cm}^{3} \mathrm{molecule}^{-1} \mathrm{sec}^{-1} \text {; } \\
& \mathrm{OT}+\mathrm{T}_{2} \longrightarrow \mathrm{T}_{2} \mathrm{O}+\mathrm{T}, \mathrm{k}_{8}=6.4 \times 10^{-15} \mathrm{~cm}^{3} \text { molecule-1 } \mathrm{sec}^{-1} \text {; } \\
& 0+\mathrm{TO}_{2} \longrightarrow \mathrm{OT}+\mathrm{O}_{2}, \mathrm{k}_{9}=1 \times 10^{-11} \mathrm{~cm}^{3} \text { molecule }-1 \mathrm{sec}^{-1} \text {. }
\end{aligned}
$$

The above sequence is characterized by the presence of the radicals $\mathrm{TO}_{2}, 0 \mathrm{~T}$, and $\mathrm{T}$, and water is produced via reactions (3.7) and (3.8). A small number of tritium atoms are removed through reaction

$$
\mathrm{T}+\mathrm{T}+\mathrm{N}_{2} \longrightarrow \mathrm{T}_{2}+\mathrm{N}_{2}
$$

which is a much slower process than reaction (3.4). Removal of $0_{2}^{+}$ions is accomplished by the three-body reaction (3.3) wherein they are converted to $0_{4}^{+}$ions and $0_{2}$ molecules. The $\mathrm{O}_{4}^{+}$ians in the presence of water, form clusters through the following reactions: 19

$$
\begin{aligned}
& \mathrm{O}_{4}^{+}+\mathrm{T}_{2} \mathrm{O} \longrightarrow \mathrm{O}_{2}^{+}\left(\mathrm{T}_{2} \mathrm{O}\right)+\mathrm{O}_{2} \\
& \mathrm{O}_{2}^{+}\left(\mathrm{T}_{2} \mathrm{O}\right)+\mathrm{T}_{2} \mathrm{O} \longrightarrow \mathrm{T}_{3} \mathrm{O}^{+}(\mathrm{OT})+\mathrm{O}_{2}
\end{aligned}
$$

The $\mathrm{N}_{2} \mathrm{~T}^{+}$ions from reaction (3.2) in the presence of tritiated water undergo the reaction 15

$$
\mathrm{N}_{2} \mathrm{~T}^{+}+\mathrm{T}_{2} \mathrm{O} \longrightarrow \mathrm{T}_{3} \mathrm{O}^{+}+\mathrm{N}_{2}
$$

and at high $T_{2} 0$ concentrations clusters are formed through the reaction with an inert gas $M$

$$
\mathrm{T}_{3}^{\prime} \mathrm{O}+\mathrm{T}_{2} \mathrm{O}+\mathrm{M} \longrightarrow \mathrm{T}_{3} \mathrm{O}^{+} \cdot\left(\mathrm{T}_{2} \mathrm{O}\right)+\mathrm{M}
$$

Higher hydrate formations up to $\mathrm{T}_{3} \mathrm{O}^{+} \cdot\left(\mathrm{T}_{2} \mathrm{O}_{4}\right.$ have been observed in mass spectrometer experiments. ${ }^{20}$ Removal of the $\mathrm{T}_{3} \mathrm{O}^{+}$ions also takes place through the electron attachment process $^{21}$

$$
\mathrm{e}+\mathrm{T}_{3} \mathrm{O}^{+} \longrightarrow \mathrm{T}+\mathrm{T}_{2} \mathrm{O}
$$

Thermalized electrons in the mixture are removed through the three-body electron attachment process 22

$$
\mathrm{e}+\mathrm{O}_{2}+\mathrm{O}_{2} \longrightarrow \mathrm{O}_{2}^{-}+\mathrm{O}_{2}, \mathrm{k}=1.87 \times 10^{-30} \mathrm{~cm}^{6} \text { molecule } \mathrm{mec}^{-1}
$$


which results in the formation of $\mathrm{O}_{2}^{-}$ions. The $\mathrm{O}_{2}^{-}$ions are neutralized through the ion-ion reaction 22

$$
0_{2}^{-}+0_{2}^{+} \longrightarrow 0_{2}^{\star}+0_{2}, k=4 \times 10^{-9} \mathrm{~cm}^{3} \text { molecule } \mathrm{e}^{-1} \mathrm{sec}^{-1} \text {. }
$$

Excited molecules $\mathrm{H}_{2}^{\star}$ and $\mathrm{O}_{2}^{\star}$ lose their excess energy through collisions and fall rapidly to a stable state. The processes of dissociative recombination and radiative attachment can be neglected since the electron density and the concentration of positive ions in these conditions are sufficiently low.

\subsubsection{Kinetics for the formation of $\mathrm{T}_{2} \mathrm{O}$}

The rate of $\mathrm{T}_{2} \mathrm{O}$ formation can be given by the equation

$$
\frac{d[T ; 0]}{d t}=k_{7}[\bar{T}]\left[\mathrm{TO}_{2}\right]+k_{8}[0 \bar{T}]\left[\bar{T}_{2}\right] \text {. }
$$

It is assumed that the free radicals $\mathrm{T}, 0,0 \mathrm{~T}$, and $\mathrm{TO}_{2}$ are in steady state, and the following equations are obtained.

$$
\begin{aligned}
& \frac{d[T]}{d t}=k_{2}\left[N_{2}^{+}\right]\left[T_{2}\right]-k_{4}[T]\left[O_{2}\right]\left[N_{2}\right]-\left(k_{5}+k_{6}+k_{7}\right)[T]\left[\mathrm{TO}_{2}\right]+k_{8}[0 T]\left[T_{2}\right]=0, \\
& \frac{d\left[\mathrm{TO}_{2}\right]}{d t}=k_{4}[T]\left[O_{2}\right]\left[N_{2}\right]-\left(k_{5}+k_{6}+k_{7}\right)[T]\left[\mathrm{TO}_{2}\right]+k_{8}[0 T]\left[\mathrm{T}_{2}\right]-k_{9}[0]\left[\mathrm{TO}_{2}\right]=0, \\
& \frac{\mathrm{d}[\mathrm{OT}]}{d t}=k_{6}[\mathrm{~T}]\left[\mathrm{TO}_{2}\right]-k_{8}[\mathrm{TO}]\left[\mathrm{T}_{2}\right]+k_{9}\left[\mathrm{TO}_{2}\right][0]=0, \\
& \frac{\mathrm{d} \mathrm{OO}]}{\mathrm{dt}}=k_{7}[\mathrm{~T}]\left[\mathrm{TO}_{2}\right]-k_{9}[0]\left[\mathrm{TO}_{2}\right]=0 .
\end{aligned}
$$

Using the above equations, the rate of $\mathrm{T}_{2} \mathrm{O}$ formation in Eq. (3.18) becomes

$$
\frac{d\left[T_{2} 0\right]}{d t}=\frac{k_{2}\left(k_{6}+2 k_{7}\right)}{2 k_{5}+k_{7}}\left[N_{2}^{+}\right]\left[T_{2}\right] \text {. }
$$

Substituting the rate constant values ${ }^{18}$ results in

$$
\frac{d\left[\mathrm{~T}_{2} 0\right]}{\mathrm{dt}}=2.45 \times 10^{-9}\left[\mathrm{~N}_{2}^{+}\right]\left[\mathrm{T}_{2}\right] \mathrm{cm}^{3} \text { molecule } \mathrm{e}^{-1} \mathrm{sec}^{-1} .
$$

The form of this expression of water formation rate is in agreement with the experimental results of Casaletto et al., ${ }^{3}$ in their experiments using mixtures of tritium, oxygen, and nitrogen,

$$
\frac{d\left[N_{2}^{+}\right]}{d t}=1.5 \times 10^{9} \text { ions } \mathrm{cm}^{-3} \mathrm{sec}^{-1},\left[\mathrm{O}_{2}\right]=3.4 \times 10^{18} \text { molecules } \mathrm{cm}^{-3} ;
$$


and $\left[T_{2}\right]=2.7 \times 10^{15}$ molecules $\mathrm{cm}^{-3}$. Since reactions (3.1) and (3.2) satisfy the relation

$$
-\frac{d\left[N_{2}^{+}\right]}{d t}=\left\{k_{1}\left[O_{2}\right]+k_{2}\left[T_{2}\right]\right\}\left[N_{2}^{+}\right]=\left\{5 \times 10^{-11}\left[\mathrm{O}_{2}\right]+2 \times 10^{-9}\left[\mathrm{~T}_{2}\right]\right\}\left[\mathrm{N}_{2}^{+}\right],
$$

it is found that

$$
\left[\mathrm{N}_{2}^{+}\right]=\dot{6} \text { ions } \mathrm{cm}^{-3} \text {. }
$$

Substituting the value of $\left[\mathrm{N}_{2}^{+}\right] \simeq 6$ molecules $\mathrm{cm}^{-3}$ in Eq. (3.20) results in

$$
\frac{d\left[T_{2} 0\right]}{d t}=1.5 \times 10^{-8}\left[T_{2}\right] \mathrm{sec}^{-1} \text {. }
$$

The above calculated value for the reaction rate constant $1.5 \times 10^{-8} \mathrm{sec}^{-1}$ is in good agreement with the experimentally found value $5.2 \times 10^{-8} \mathrm{sec}^{-1}$ for a mixture of tritium, oxygen, and nitrogen. ${ }^{3}$

\subsection{Tritium, 0xygen, and Argon Mixture}

Experiments with mixtures of tritium, oxygen, and argon were performed by Belovodski i et al. ${ }^{5}$ In these experiments the main component gas was argon, the total pressure of the mixture was $600-700 \mathrm{~mm}$, and the oxygen concentration was $20 \%$ of the total. Irradiation of such a mixture results in the formation of $\mathrm{Ar}^{+}, \mathrm{O}_{2}^{+}$, and $\mathrm{T}_{2}^{+}$ions and $\mathrm{Ar}^{\star}, \mathrm{O}_{2}^{\star}$, and $\mathrm{T}_{2}^{\star}$, excited molecules. The ionic and excitation processes are

$$
\begin{aligned}
A \mathrm{Ar}^{+} \mathrm{e} & \longrightarrow A r^{+}+2 \mathrm{e}, \\
& \longrightarrow A r^{\star}+\mathrm{e}, \\
\mathrm{O}_{2}+\mathrm{e} & \longrightarrow 0_{2}^{+}+2 \mathrm{e}, \\
& \longrightarrow 0_{2}^{+}+\mathrm{e}, \\
\mathrm{T}_{2}+\mathrm{e} & \longrightarrow \mathrm{T}_{2}^{+}+2 \mathrm{e}, \\
& \longrightarrow \mathrm{T}_{2}^{\star}+\mathrm{e} .
\end{aligned}
$$

The $\mathrm{Ar}^{+}$ions are the main positive ions in the mixture and probably undergo the reactions: ${ }^{15}$

$$
\begin{aligned}
& \mathrm{Ar}^{+}+\mathrm{O}_{2} \longrightarrow \mathrm{O}_{2}^{+}+\mathrm{Ar}, \quad \mathrm{k}_{1}=5 \times 10^{-11} \mathrm{~cm}^{3} \text { molecule } \\
& \mathrm{Ar}^{+}+\mathrm{T}_{2} \longrightarrow \mathrm{sec}^{-1}
\end{aligned}
$$

The reaction (3.22) is predominant, especially for higher oxygen concentrations. The $T_{2}^{+}$ions can also induce the reaction 15

$$
\mathrm{T}_{2}^{+}+\mathrm{Ar} \longrightarrow \mathrm{ArT}^{+}+\mathrm{T}, \mathrm{k}_{3}=1.2 \times 10^{-9} \mathrm{~cm}^{3} \text { molecule } \mathrm{e}^{-1} \mathrm{sec}^{-1},
$$


but its contribution to the formation of $T$ atoms is negligible in comparison with reaction (3.23). Removal of $\mathrm{O}_{2}^{+}$ions is through the reactions described in Sect. 3.1.1.

Reaction (3.23) results in the formation of $\mathrm{ArT}^{+}$ions and tritium atoms. In the presence of tritiated water, the $\mathrm{ArT}^{+}$ions undergo reactions similar to Eqs. 3.13 and 3.14.

The tritium atoms induce a number of radical reactions similar to those discussed in Sect. 3.1.1, and the production of $\mathrm{T}_{2} \mathrm{O}$ can be given by the equation:

$$
\frac{d\left[T_{2} 0\right]}{d t}=\frac{k_{2}\left(k_{6}+2 k_{7}\right)}{2 k_{5}+k_{7}}\left[\mathrm{Ar}^{+}\right]\left[T_{2}\right] \text {, }
$$

where $k_{2}$ is the rate constant of the reaction (3.23). Substituting the rate constant values ${ }^{18}$ results in

$$
\frac{d\left[\mathrm{~T}_{2} \mathrm{O}\right]}{d \mathrm{t}}=8.12 \times 10^{-10}\left[\mathrm{Ar}^{+}\right]\left[\mathrm{T}_{2}\right] \mathrm{cm}^{3} \text { molecule } \mathrm{e}^{-1} \mathrm{sec}^{-1}
$$

In these experiments, for a mixture with total pressure $\sim 600 \mathrm{~mm}$, the components are $400 \mathrm{~mm}$ argon, $[\mathrm{Ar}]=1.5 \times 10^{19}$ molecules $\mathrm{cm}^{-3} ; 120 \mathrm{~mm}$ oxygen, $\left[\mathrm{O}_{2}\right]=3.9 \times 10^{18}$ molecules $\mathrm{cm}^{-3}$; and 90 to $0.09 \mathrm{Ci}^{1}$ iter ${ }^{-1}$ tritium, $\left[\mathrm{T}_{2}\right]=9.2 \times 10^{17}$ to $9.2 \times 10^{14}$ molecules $\mathrm{cm}^{-3}$. The rate $d\left[\mathrm{Ar}^{+}\right] / d t$ can be estimated for the various values of $\left[\mathrm{T}_{2}\right]$, see Table 3 . Since reactions (3.22) and (3.23) satisfy the relation

$$
-\frac{\mathrm{d}\left[\mathrm{Ar}^{+}\right]}{\mathrm{dt}}=\left\{\mathrm{k}_{1}\left[\mathrm{O}_{2}\right]+\mathrm{k}_{2}\left[\mathrm{~T}_{2}\right]\right\}\left[\mathrm{Ar}^{+}\right]=\left\{5 \times 10^{-11}\left[\mathrm{O}_{2}\right]+7 \times 10^{-10}\left[\mathrm{~T}_{2}\right]\right\}\left[\mathrm{Ar}^{+}\right] \text {; }
$$

the values of $\left[\mathrm{Ar}^{+}\right]$can be found, and substitution in Eq. (3.26) results in the estimation of the calculated rate $d\left[\mathrm{~T}_{2} 0\right] / d t$, see Table 3 . These calculated reaction

\begin{tabular}{|c|c|c|c|c|}
\hline $\begin{aligned} & {\left[\mathrm{T}_{2}\right] } \\
& \mathrm{Ci} \text { liter }-1 \\
&\end{aligned}$ & $\begin{array}{c}\frac{\mathrm{d}\left[\mathrm{Ar}^{+}\right]}{\mathrm{dt}} \\
\text { jons } \mathrm{cm}^{-3} \mathrm{sec}^{-1}\end{array}$ & $\begin{array}{c}\quad\left[\mathrm{Ar}^{+}\right] \\
\text {ions } \mathrm{cm}^{-3}\end{array}$ & $\frac{d\left[\mathrm{~T}_{2} \mathrm{O}\right]}{\mathrm{dt}} \mathrm{cal}$ & $\begin{array}{l}\frac{d\left[\mathrm{~T}_{2} 0\right]}{\mathrm{dt}} \exp \\
\text { Ci liter-1 } \text { min }^{-1}\end{array}$ \\
\hline 90 & $2.2 \times 10^{11}$ & 262 & $1.15 \times 10^{-3}$ & $1.8 \times 10^{-3}$ \\
\hline 19.6 & $5.3 \times 10^{10}$ & 158 & $1.5 \times 10^{-4}$ & $1.11 \times 10^{-4}$ \\
\hline 7.4 & $1.6 \times 10^{10}$ & 65 & $2.3 \times 10^{-5}$ & $2.8 \times 10^{-5}$ \\
\hline 0.2 & $4.5 \times 10^{8}$ & 2.3 & $2.25 \times 10^{-8}$ & $7 \times 10^{-8}$ \\
\hline 0.09 & $2.1 \times 10^{8}$ & 1.1 & $0.49 \times 10^{-8}$ & $2 \times 10^{-8}$ \\
\hline
\end{tabular}
rate constants are in good agreement with the experimentaliy found rate constants.

Table.3. Calculated and experimental rates of HTO formation

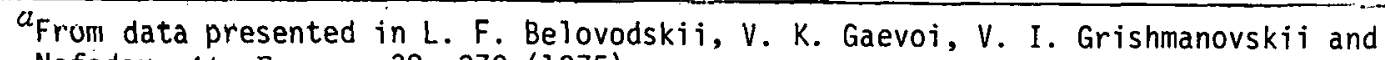
N. V. Nefedov, At. Energ., 38, 379 (1975). 


\subsection{Tritium, Water, and Helium Mixture}

The mixture of tritium, water, and helium was examined experimentally by Yang and Gevantman. ${ }^{2}$ In their experiments, the concentration of helium was much higher than that of water vapor. (The $\mathrm{O}_{2}$ molecule concentration is taken to be $0.001 \%$ of the helium atom concentration; this amount of impurity is expected to be present in a research grade helium gas sample.) The rates of formation for $\mathrm{He}^{+}$ions was $210^{9}$ to $10^{8}$ ions $\mathrm{cm}^{-3} \mathrm{sec}^{-1}$, for $\dot{H}_{2} \mathrm{O}^{+}$ions $\sim 10^{6}$ to $10^{5}$ ions $\mathrm{cm}^{-3} \mathrm{sec}^{-1}$, and for $\mathrm{T}_{2}^{+}$ions $\sim 1$ to $10^{2}$ ions $\mathrm{cm}^{-3} \mathrm{sec}^{-1}$. Irradiation of the above mixture results in the following primary ionic and excitation processes.

$$
\begin{aligned}
\mathrm{He}+\mathrm{e} & \longrightarrow \mathrm{He}^{+}+2 \mathrm{e}, \\
& \cdots \cdots \rightarrow \mathrm{He}^{*}+\mathrm{e}, \\
\mathrm{H}_{2} \mathrm{O}+\mathrm{e} \longrightarrow \mathrm{H}_{2} \mathrm{O}^{+}+2 \mathrm{e}, & \longrightarrow \mathrm{OH}^{+}+\mathrm{H}+2 \mathrm{e}, \\
& \longrightarrow \mathrm{H}_{2} \mathrm{O}^{\star}+\mathrm{e}, \\
\mathrm{T}_{2}+\mathrm{e} & \longrightarrow \mathrm{T}_{2}^{+}+2 \mathrm{e}, \\
& \longrightarrow \mathrm{T}_{2}{ }^{\star}+\mathrm{e} .
\end{aligned}
$$

The occurrence of $\mathrm{H}_{2} \mathrm{O}^{+}$and $\mathrm{OH}^{+}$ions, formed by reacting thermal energy $\mathrm{He}^{+}$ions with $\mathrm{H}_{2} \mathrm{O}$, has been observed in mass spectroscopy experiments, ${ }^{23}$ and their relative concentrations in ions $\mathrm{cm}^{-3}$ were found to be $17 \%$ and $83 \%$, respectively. The positive ions produce the following ion-molecule reactions: 15,24

$$
\begin{aligned}
\mathrm{He}^{+}+\mathrm{H}_{2} \mathrm{O} \longrightarrow \mathrm{H}_{2} \mathrm{O}^{+}+\mathrm{He}, & \mathrm{k}_{1}=9.5 \times 10^{-11} \mathrm{~cm}^{3} \text { molecule-1 } \mathrm{sec}^{-1} ; \\
\longrightarrow \mathrm{OH}^{+}+\mathrm{H}+\mathrm{He}, & \mathrm{k}_{2}=4.6 \times 10^{-10} \mathrm{~cm}^{3} \text { molecule }{ }^{-1} \mathrm{sec}^{-1} ; \\
\mathrm{H}_{2} \mathrm{O}^{+}+\mathrm{H}_{2} \mathrm{O} \longrightarrow \mathrm{H}_{3} \mathrm{O}^{+}+\mathrm{OH}, & \mathrm{k}_{3}=1.8 \times 10^{-9} \mathrm{~cm}^{3} \text { molecule } \mathrm{sec}^{-1} ; \\
\mathrm{H}_{2} \mathrm{O}^{+}+\mathrm{T}_{2} \longrightarrow \mathrm{H}_{2} \mathrm{HO}^{+}+\mathrm{T}, & \mathrm{k}_{4}=1.4 \times 10^{1.9} \mathrm{~cm}^{3} \text { molecule } \mathrm{sec}^{-1} ; \\
\mathrm{OH}^{+}+\mathrm{H}_{2} \mathrm{O} \longrightarrow \mathrm{H}_{3} \mathrm{O}^{+}+\mathrm{O}, & \mathrm{k}_{5}=1.5 \times 10^{-9} \mathrm{~cm}^{3} \text { molecule } \mathrm{sec}^{-1} ; \\
\mathrm{T}_{2}^{+}+\mathrm{T}_{2} \longrightarrow \mathrm{T}_{3}^{+}+\mathrm{T}, & \mathrm{k}_{6}=2 \times 10^{-9} \mathrm{~cm}^{3} \text { molecule } \mathrm{sec}^{-1} .
\end{aligned}
$$

Reactions with $T_{2},(3.31)$ and (3.33), are the least likely since the concentration of tritium is less than that of water. The main products of the above ion-molecule reactions are $\mathrm{H}_{3} \mathrm{O}^{+}$ions and $\mathrm{OH}, \mathrm{H}$, and $\mathrm{T}$ free radicals. The $\mathrm{H}_{3} \mathrm{O}^{+}$ions in the presence of water form clusters through the reaction with an inert gas $M$ :

$$
\mathrm{H}_{3} \mathrm{O}^{+}+\mathrm{H}_{2} \mathrm{O}+\mathrm{M} \longrightarrow \mathrm{H}_{3} \mathrm{O}^{+} \cdot\left(\mathrm{H}_{2} \mathrm{O}\right)+\mathrm{M}
$$


or through the electron attachment process

$$
\mathrm{H}_{3} \mathrm{O}^{+}+\mathrm{e} \longrightarrow \mathrm{H}+\mathrm{H}_{2} \mathrm{O}
$$

Higher hydrate formations occur up to $\mathrm{H}_{3} \mathrm{O}^{+} \cdot\left(\mathrm{H}_{2} \mathrm{O}\right)_{4}: 20$

The $\mathrm{OH}, \mathrm{H}$ or $\mathrm{T}$, and 0 free radicals induce a number of free radical reactions, ${ }^{18}$ as follows:

$$
\begin{aligned}
& \mathrm{H}+\mathrm{H}+\mathrm{He} \longrightarrow \mathrm{H}_{2}+\mathrm{He}, \quad \mathrm{k}=1.3 \times 10^{-32} \mathrm{~cm}^{6} \text { molecule-2 } \mathrm{sec}^{-1} \text {; } \\
& \mathrm{H}+\mathrm{OH}+\mathrm{He} \longrightarrow \mathrm{H}_{2} \mathrm{O}+\mathrm{He}, \quad \mathrm{k}=6.9 \times 10^{-31} \mathrm{~cm}^{6} \text { molecule }{ }^{-2} \mathrm{sec}^{-1} \text {; } \\
& \mathrm{OH}+\mathrm{OH}+\mathrm{He} \longrightarrow \mathrm{H}_{2} \mathrm{O}_{2}+\mathrm{He}, \mathrm{k}=2.5 \times 10^{-31} \mathrm{~cm}^{6} \text { molecule } \mathrm{Hec}^{-1} \text {; } \\
& \mathrm{O}+\mathrm{OH} \longrightarrow \mathrm{O}_{2}+\mathrm{H}, \quad \mathrm{k}=3.8 \times 10^{-11} \mathrm{~cm}^{3} \text { molecule } \mathrm{Hec}^{-1} \text {; } \\
& \mathrm{H}+\mathrm{O}_{2}+\mathrm{He} \longrightarrow \mathrm{HO}_{2}+\mathrm{He}, \quad \mathrm{k}=2.1 \times 10^{-32} \mathrm{~cm}^{6} \text { molecule } \mathrm{esec}^{-1} \text {; } \\
& \mathrm{H}+\mathrm{HO}_{2} \longrightarrow \mathrm{H}_{2}+\mathrm{O}_{2}, \quad \mathrm{k}=1.3 \times 10^{-11} \mathrm{~cm}^{3} \text { molecule }-1 \mathrm{sec}^{-1} \text {; } \\
& \mathrm{H}+\mathrm{HO}_{2} \longrightarrow \mathrm{OH}+\mathrm{OH}, \quad \mathrm{k}=1.7 \times 10^{-11} \mathrm{~cm}^{3} \text { molecule } \mathrm{Hec}^{-1} \mathrm{sec}^{-1} \text {; } \\
& \mathrm{H}+\mathrm{HO}_{2} \longrightarrow \mathrm{H}_{2} \mathrm{O}+\mathrm{O}, \quad \mathrm{k}=1.6 \times 10^{-11} \mathrm{~cm}^{3} \text { molecule } \mathrm{sec}^{-1} \text {; } \\
& \mathrm{HO}_{2}+\mathrm{HO}_{2} \longrightarrow \mathrm{H}_{2} \mathrm{O}_{2}+\mathrm{O}_{2}, \quad \mathrm{k}=3.1 \times 10^{-12} \mathrm{~cm}^{3} \text { molecule } \mathrm{sec}^{-1} \text {; } \\
& \mathrm{H}+\mathrm{O}+\mathrm{He} \longrightarrow \mathrm{UH}+\mathrm{Hè}, \quad \mathrm{k}=2.5 \times 10^{-\hat{3}<} \mathrm{cm}^{b} \text { molecule } \mathrm{e}^{-2} \mathrm{sec}^{-1} \text {; } \\
& \mathrm{H}+\mathrm{H}_{2} \mathrm{O}_{2} \longrightarrow \mathrm{H}_{2} \mathrm{O}+\mathrm{OH}, \quad \mathrm{K}=4.6 \times 10^{-14} \mathrm{~cm}^{3} \text { molecule } \mathrm{Hec}^{-1} \mathrm{sec}^{-1} \text {; } \\
& \mathrm{OH}+\mathrm{H}_{2} \mathrm{O}_{2} \longrightarrow \mathrm{H}_{2} \mathrm{O}+\mathrm{HO}_{2}, \quad \mathrm{k}=8 \times 10^{-13} \mathrm{~cm}^{3} \text { molecule-1 } \mathrm{sec}^{-1} \text {; } \\
& \mathrm{OH}+\mathrm{H}_{2} \longrightarrow \mathrm{H}_{2} \mathrm{O}+\mathrm{H}, \quad \mathrm{k}=7.4 \times 10^{-15} \mathrm{~cm}^{3} \text { molecule } \mathrm{sec}^{-1} \text {; } \\
& \mathrm{OH}+\mathrm{OH} \longrightarrow \mathrm{H}_{2} \mathrm{O}+\mathrm{O}, \quad \mathrm{K}=1.7 \times 10^{-12} \mathrm{~cm}^{3} \text { molecule } \mathrm{Hec}^{-1} \mathrm{sec}^{-1} \\
& 0+\mathrm{O}+\mathrm{He} \longrightarrow \mathrm{O}_{2}+\mathrm{He}, \quad \mathrm{k}=4.8 \times 10^{-33} \mathrm{~cm}^{6} \text { molecule }-2 \mathrm{sec}^{-1} \text {; } \\
& 0+\mathrm{H}_{2} \longrightarrow \mathrm{H}+\mathrm{OH}, \quad \mathrm{k}=2.6 \times 10^{-18} \mathrm{~cm}^{3} \text { molecule } \mathrm{mec}^{-1} \text {; } \\
& \mathrm{OH}+\mathrm{HO}_{2} \longrightarrow \mathrm{H}_{2} \mathrm{O}+\mathrm{O}_{2}, \quad \mathrm{k}=2 \times 10^{-10} \mathrm{~cm}^{3} \text { molecule } \mathrm{mec}^{-1} \text {; } \\
& 0+\mathrm{HO}_{2} \longrightarrow \mathrm{OH}+\mathrm{O}_{2}, \quad \mathrm{k}=1 \times 10^{-11} \mathrm{~cm}^{3} \text { molecule } \mathrm{sec}^{-1} \text {; } \\
& \mathrm{O}+\mathrm{O}_{2}+\mathrm{He} \longrightarrow \mathrm{O}_{3}+\mathrm{He}, \quad \mathrm{k}=6.1 \times 10^{-34} \mathrm{~cm}^{6} \text { molecule } \mathrm{mec}^{-1} \text {; } \\
& 0+\mathrm{O}_{3} \longrightarrow \mathrm{O}_{2}+\mathrm{O}_{2}, \quad \mathrm{k}=8.4 \times 10^{-15} \mathrm{~cm}^{3} \text { molecule } \mathrm{e}^{-1} \mathrm{sec}^{-1} \text { : } \\
& \mathrm{O}_{3}+\mathrm{H} \longrightarrow \mathrm{OH}+\mathrm{O}_{2}, \quad \mathrm{k}=2.6 \times 10^{-11} \mathrm{~cm}^{3} \text { molecule }-1 \mathrm{sec}^{-1} \text {; } \\
& \mathrm{O}_{3}+\mathrm{OH} \longrightarrow \mathrm{HO}_{2}+\mathrm{O}_{2}, \quad \mathrm{k}=5.4 \times 10^{-14} \mathrm{~cm}^{3} \text { molecule } \mathrm{Hec}^{-1} \text {; } \\
& \mathrm{O}_{3}+\mathrm{HO}_{2} \longrightarrow \mathrm{OH}+2 \mathrm{O}_{2}, \quad \mathrm{k}=1.5 \times 10^{-15} \mathrm{~cm}^{3} \text { molecule } \mathrm{Hec}^{-1} \text {. }
\end{aligned}
$$


From these reactions, water is formed in a number of ways. In order to determine the reaction or reactions that are predominant in the water formation, the relative concentrations of the free radicals should be known. An estimation of the order of magnitude of the free radicals concentration can be done in two steps. At first, the rate of formation of $\mathrm{OH}, \mathrm{H}$, or $\mathrm{T}$, and 0 radicals is evaluated by assuming the steady state condition for the $\mathrm{He}^{+}, \mathrm{H}_{2} \mathrm{O}^{+}$, and $\mathrm{T}_{2}^{+}$ions. Then by assuming the steady state condition for the $\mathrm{H}$ or. $\mathrm{T}, \mathrm{OH}, \mathrm{HO}_{2}, \mathrm{H}_{2} \mathrm{O}_{2}, \mathrm{O}$, and $\mathrm{O}_{3}$ radicals, it can be found that $[\mathrm{H}] \sim 10^{7}$ to $10^{8}$ molecules $\mathrm{cm}^{-3}$, $[\mathrm{OH}] \sim 10^{6}$ molecules $\mathrm{cm}^{-3},\left[\mathrm{HO}_{2}\right] \sim 10^{10}$ molecules $\mathrm{cm}^{-3},\left[\mathrm{H}_{2} \mathrm{O}_{2}\right] \sim 10^{13}$ to $10^{14}$ molecules $\mathrm{cm}^{-3}$, [0] $\sim 10^{8}$ to $10^{10}$ molecules $\mathrm{cm}^{-3},\left[\mathrm{O}_{2}\right] \sim 10^{14}$ molecules $\mathrm{cm}^{-3}$, and $\left[\mathrm{O}_{3}\right] \sim 10^{9}$ to $10^{11}$ molecules $\mathrm{cm}^{-3}$. Using these estimates the most predominant reactions are

$$
\begin{aligned}
& \mathrm{H}+\mathrm{O}_{2}+\mathrm{He} \longrightarrow \mathrm{HO}_{2}+\mathrm{He}, \quad \mathrm{kg}_{\mathrm{g}}=1 \times 10^{-31} \mathrm{~cm}^{6} \text { molecule }{ }^{-2} \mathrm{sec}^{-1} ; \\
& \mathrm{H}+\mathrm{HO}_{2} \longrightarrow \mathrm{H}_{2}+\mathrm{O}_{2}, \quad \mathrm{k}_{10}=1.3 \times 10^{-11} \mathrm{~cm}^{3} \text { molecule } \mathrm{e}^{-1} \mathrm{sec}^{-1} \text {; } \\
& \mathrm{H}+\mathrm{HO}_{2} \longrightarrow \mathrm{OH}+\mathrm{OH}, \quad k_{11}=1.7 \times 10^{-11} \mathrm{~cm}^{3} \text { molecule } \mathrm{Hec}^{-1} \text {; } \\
& \mathrm{H}+\mathrm{HO}_{2} \longrightarrow \mathrm{H}_{2} \mathrm{O}+\mathrm{O}, \quad \mathrm{k}_{12}=1.6 \times 10^{-11} \mathrm{~cm}^{3} \text { molecule-1 } \mathrm{sec}^{-1} \text {; } \\
& \mathrm{HO}_{2}+\mathrm{HO}_{2} \longrightarrow \mathrm{H}_{2} \mathrm{O}_{2}+\mathrm{O}_{2}, \quad \mathrm{k}_{13}=3.1 \times 10^{-12} \mathrm{~cm}^{3} \text { molecule } \mathrm{sec}^{-1} \text {; } \\
& \mathrm{H}+\mathrm{H}_{2} \mathrm{O}_{2} \longrightarrow \mathrm{H}_{2} \mathrm{O}+\mathrm{OH}, \quad \mathrm{k}_{14}=4.6 \times 10^{-14} \mathrm{~cm}^{3} \text { molecule-1 } \mathrm{sec}^{-1} \text {; } \\
& \mathrm{OH}+\mathrm{H}_{2} \mathrm{O}_{2} \longrightarrow \mathrm{H}_{2} \mathrm{O}+\mathrm{HO}_{2}, \mathrm{k}_{15}=8 \times 10^{-13} \mathrm{~cm}^{3} \text { molecule }{ }^{-1} \mathrm{sec}^{-1} \text {; } \\
& \mathrm{OH}+\mathrm{H}_{2} \longrightarrow \mathrm{H}_{2} \mathrm{O}+\mathrm{H}, \quad \mathrm{k}_{16}=7.4 \times 10^{-15} \mathrm{~cm}^{3} \text { molecule }{ }^{-1} \mathrm{sec}^{-1} \text {; } \\
& \mathrm{OH}+\mathrm{HO}_{2} \longrightarrow \mathrm{H}_{2} \mathrm{O}+\mathrm{O}_{2}, \quad \mathrm{k}_{17}=2 \times 10^{-10} \mathrm{~cm}^{3} \text { molecule-1 } \mathrm{sec}^{-1} \text {; } \\
& \mathrm{O}+\mathrm{HO}_{2} \longrightarrow \mathrm{OH}+\mathrm{O}_{2}, \quad \mathrm{k}_{18}=1 \times 10^{-11} \mathrm{~cm}^{3} \text { molecule-1 } \mathrm{sec}^{-1} \text {; } \\
& \mathrm{O}+\mathrm{H}_{2} \longrightarrow \mathrm{H}+\mathrm{OH}, \quad \mathrm{k}_{19}=2.6 \times 10^{-18} \mathrm{~cm}^{3} \text { molecule } \mathrm{mec}^{-1} \mathrm{sec}^{-1} \text {; } \\
& 0+\mathrm{O}_{2}+\mathrm{He} \longrightarrow \mathrm{O}_{3}+\mathrm{He}, \quad k_{20}=6.1 \times 10^{-34} \mathrm{~cm}^{6} \text { molecule } \mathrm{e}^{-2} \mathrm{sec}^{-1} \text {; } \\
& \mathrm{O}_{3}+\mathrm{H} \longrightarrow \mathrm{OH}+\mathrm{O}_{2}, \quad \mathrm{k}_{21}=2.6 \times 10^{-11} \mathrm{~cm}^{3} \text { molecule }{ }^{-1} \mathrm{sec}^{-1} \text {. }
\end{aligned}
$$

From the above sequence of reactions, the rate of water formation is given by the relation

$\frac{d\left[\mathrm{H}_{2} \mathrm{O}\right]}{\mathrm{dt}}=k_{12}[\mathrm{H}]\left[\mathrm{HO}_{2}\right]+k_{14}[\mathrm{H}]\left[\mathrm{H}_{2} \mathrm{O}_{2}\right]+k_{15}[\mathrm{OH}]\left[\mathrm{H}_{2} \mathrm{O}_{2}\right]+k_{16}[\mathrm{OH}]\left[\mathrm{H}_{2}\right]+k_{17}[\mathrm{OH}]\left[\mathrm{HO}_{2}\right]$.

ror the average mixture, $[\mathrm{He}]=2 \times 10^{19}$ molecules $\mathrm{cm}^{-3},\left[\mathrm{H}_{2} \mathrm{O}\right]=4.1 \times 10^{17}$ molecules $\mathrm{cm}^{-3}$, and $\left[\mathrm{T}_{2}\right]=1 \times 10^{15}$ molecules $\mathrm{cm}^{-3}$, it can be found that $[\mathrm{H}] \sim 10^{7}$ molecules $\mathrm{cm}^{-3}$ and $\left[\mathrm{H}_{2} \mathrm{O}_{2}\right] \sim 10^{13}$ molecules $\mathrm{cm}^{-3}$. By substituting in Eq. (3.49), it is found that

$$
\frac{d\left[\mathrm{H}_{2} \mathrm{O}\right]}{\mathrm{dt}}=2.36 \times 10^{7} \text { molecules } \mathrm{cm}^{-3} \mathrm{sec}^{-1},
$$


which is approximately equal to the experimental value $\mathrm{d}[\mathrm{HTO}] / \mathrm{dt}=5.1 \times 10^{7}$ molecules $\mathrm{cm}^{-3} \mathrm{sec}^{-1}$, obtained by Yang and Gevantman. ${ }^{2}$ It can also be shown that for all mixtures the theoretically determined rate of water formation, using Eq. (3.49), is the same order of magnitude as the experimental rate. ${ }^{2}$ Therefore, Eq. (3.49) gives an approximate expression of the rate of water formation.

In an experiment where nitric oxide, a free radical scavenger, was introduced in the mixture, ${ }^{2}$ a strong reduction was observed in the formation of tritiated water. Namely, for $[\mathrm{NO}]=3.58\left[\mathrm{~T}_{2}\right]$ the rate of water formation was $4 \%$ of the expected without NO. This was due to the strong scavenging effect of $\mathrm{NO}$ on $\mathrm{H}$ and $\mathrm{OH}$ radicals. The reactions ${ }^{18}$

$$
\begin{array}{ll}
\mathrm{OH}+\mathrm{NO}+\mathrm{He} \longrightarrow \mathrm{HNO}_{2}+\mathrm{He}, \quad \mathrm{k}=9.2 \times 10^{-32} \mathrm{~cm}^{6} \text { molecule } \\
& =\mathrm{sec}^{-1}, \\
\mathrm{H}+\mathrm{NO}+\mathrm{He} \longrightarrow \mathrm{HNO}+\mathrm{He}, & \mathrm{k}=2 \times 10^{-32} \mathrm{~cm}^{6} \text { molecule }{ }^{-2} \mathrm{sec}^{-1}
\end{array}
$$

are more predominant than reactions (3.39), (3.41) to (3.44) which result in the formation of water. 


\section{DISCUSSION AND CONCLUSIONS}

\subsection{Basic Mechanisms of HTO Formation}

The conversion mechanisms of tritium to tritiated water have been examined for the three gaseous mixtures $\left(T_{2}, \mathrm{O}_{2}, \mathrm{~N}_{2}\right),\left(\mathrm{T}_{2}, \mathrm{O}_{2}, \mathrm{Ar}\right)$, and $\left(\mathrm{T}_{2}, \mathrm{H}_{2} \mathrm{O}, \mathrm{He}\right)$.

For the tritium, oxygen, and inert gas mixtures, the mechanism of conversion starts with the formation of tritium atoms through the reaction

$$
M^{+}+T_{2} \longrightarrow T M^{+}+T
$$

where $M$ is an inert gas. The tritium atoms react with oxygen and inert gas molecules through the reaction

$$
\mathrm{T}+\mathrm{O}_{2}+\mathrm{M} \longrightarrow \mathrm{TO}_{2}+\mathrm{M}
$$

which then initiates a number of radical reactions, leading to the formation of water. It has been found that the calculated rate of water formation is about equal to the experimental rate.

For the tritium, water, and helium mixture, the nrimary ionic and excitation processes result in the formation of $\mathrm{He}^{+}, \mathrm{H}_{2} \mathrm{O}^{+}$, and $\mathrm{OH}^{+}$ions, which induce the ionmolecule reactions:

$$
\begin{aligned}
& \mathrm{He}^{+}+\mathrm{H}_{2} \mathrm{O} \longrightarrow \mathrm{H}_{2} \mathrm{O}^{+}+\mathrm{He}, \\
& \longrightarrow \mathrm{OH}^{+}+\mathrm{H}+\mathrm{He}, \\
& \mathrm{H}_{2} \mathrm{O}^{+}+\mathrm{H}_{2} \mathrm{O} \longrightarrow \mathrm{H}_{3} \mathrm{O}^{+}+\mathrm{OH}, \\
& \mathrm{OH}^{+}+\mathrm{H}_{2} \mathrm{O} \longrightarrow \mathrm{H}_{3} \mathrm{O}^{+}+\mathrm{O} .
\end{aligned}
$$

The $\mathrm{H}_{3} \mathrm{O}^{+}$ions form ion clusters and the $\mathrm{OH}, \mathrm{H}$ or $\mathrm{T}$, and $\mathrm{O}$ radicals initiate a number of radical reactions resulting in the formation of water. The $0.001 \%$ oxygen impurity in helium has been found sufficient to initiate adequate numbers of the important reaction

$$
\mathrm{H}+\mathrm{O}_{2}+\mathrm{He} \longrightarrow \mathrm{HO}_{2}+\mathrm{He},
$$

which then induce the rest of the radical reactions. A lower $\mathrm{O}_{2}$ molecule concentration will reduce the occurrence of reaction (4.7) and therefore change the course of the subsequent radical reactions. Hence, in a tritfum mixture, the relative $\mathrm{O}_{2}$ molecules concentration is very important in the final formation of water which takes place through the following reactions: 


$$
\begin{aligned}
& \mathrm{H}+\mathrm{HO}_{2} \rightarrow \mathrm{H}_{2} \mathrm{O}+\mathrm{O}, \\
& \mathrm{H}+\mathrm{H}_{2} \mathrm{O}_{2} \rightarrow \mathrm{H}_{2} \mathrm{O}+\mathrm{OH}, \\
& \mathrm{OH}+\mathrm{H}_{2} \mathrm{O}_{2} \rightarrow \mathrm{H}_{2} \mathrm{O}+\mathrm{HO}_{2}, \\
& \mathrm{OH}+\mathrm{H}_{2} \rightarrow \mathrm{H}_{2} \mathrm{O}+\mathrm{H}, \\
& \mathrm{OH}+\mathrm{HO}_{2} \rightarrow \mathrm{H}_{2} \mathrm{O}+\mathrm{O}_{2},
\end{aligned}
$$

From the above sequence of reactions, the importance of the $\mathrm{OH}$, and $\mathrm{H}$ radicals in the formation of tritiated water, even in a moist gas mixture, becomes apparent. The introduction of a strong free radical scavenger, such as nitric oxide, results in the inhibition of the above reactions, and therefore the reduction of the tritiated water formation.

\subsection{Prevention of HTO Formation}

For tritium mixtures without water vapor, the formation of tritium atoms through ion-molecule reactions appears to be a very important process for the final formation of tritiated water. The tritium atoms initiate the radical reactions that result in the formation of HTO. Therefore, a method should be found either to prevent the formation of tritium atoms or to remove or to reduce them before they initiate the radical reactions. Then it would be possible to prevent or to reduce the formation of HTO.

In order to minimize the formation of tritium atoms, the ion-molecule reaction that produces the tritium atoms must be reduced. Therefore, a more efficient competing ionmolecule reaction should be encouraged by introducing into the mixture an appropriate additive gas. Further, the removal or reduction of the number of tritium atoms before they initiate radical reactions can be accomplished by introducing into the mixture a tritium-atom scavenger. Such a tritium-atom scavenger should romove all tritium aluins and result in a tritium-iabeled compound less hazardous than HTO. The gases $\mathrm{C}_{2} \mathrm{H}_{4}$ and $\mathrm{C}_{3} \mathrm{H}_{6}$ have been used as scavergers of hydrogen atoms in the gamma radiolysis of ethane, propane, $n$-butane and $n$-pentane. ${ }^{25}$ Thus, hydrocarbons could be used as effective scavengers of hydrogen atoms. A number of possible reactions hetween hydrogen atoms and hydrocarbons, together with their rate constants, 18 are 7 isted:

$$
\begin{aligned}
& \mathrm{H}+\mathrm{CH}_{4} \longrightarrow \mathrm{H}_{2}+\mathrm{CH}_{3}, \quad \mathrm{k}=3.7 \times 10^{-y} \mathrm{~cm}^{3} \text { molecule } \mathrm{sec}^{-1} \text {; } \\
& \mathrm{H}+\mathrm{C}_{2} \mathrm{H}_{6} \longrightarrow \mathrm{H}_{2}+\mathrm{C}_{2} \mathrm{H}_{5}, \quad \mathrm{k}=4.5 \times 10^{-18} \mathrm{~cm}^{3} \mathrm{mnl} \text { frille-1 } \mathrm{sec}^{-1} \text {; } \\
& \mathrm{H}+\mathrm{n}-\mathrm{C}_{4} \mathrm{H}_{10} \longrightarrow \mathrm{H}_{2}+\mathrm{sec}-\mathrm{C}_{4} \mathrm{H}_{9}, \mathrm{k}=3.2 \times 10^{-16} \mathrm{~cm}^{3} \text { molecule } \mathrm{sec}^{-1} \text {; } \\
& \mathrm{H}+\mathrm{C}_{2} \mathrm{H}_{4} \longrightarrow \mathrm{C}_{2} \mathrm{H}_{5}, \quad \mathrm{k}=1.4 \times 10^{-12} \mathrm{~cm}^{3} \text { molecule } \mathrm{sec}^{-1} \text {; } \\
& \mathrm{H}+\mathrm{C}_{3} \mathrm{H}_{6} \longrightarrow \mathrm{C}_{3} \mathrm{H}_{7}, \quad \mathrm{k}=1.6 \times 10^{-12} \mathrm{~cm}^{3} \text { molecule } \mathrm{sec}^{-1} \text {; } \\
& \mathrm{H}+\mathrm{C}_{4} \mathrm{H}_{8} \longrightarrow \mathrm{C}_{4} \mathrm{H}_{9}, \quad \mathrm{k}=1.4 \times 10^{-12} \mathrm{~cm}^{3} \text { molecule } \mathrm{esec}^{-1} \text {; } \\
& \mathrm{H}+\mathrm{C}_{4} \mathrm{H}_{6} \longrightarrow \mathrm{C}_{4} \mathrm{H}_{7}, \quad \mathrm{~K}=8.3 \times 10^{-12} \mathrm{~cm}^{3} \text { molecule-1 } \mathrm{sec}^{-1} \text {; }
\end{aligned}
$$




$$
\begin{array}{ll}
\mathrm{H}+\mathrm{C}_{6} \mathrm{H}_{12} \longrightarrow \mathrm{C}_{6} \mathrm{H}_{13}, & \mathrm{k}=1.2 \times 10^{-12} \mathrm{~cm}^{3} \text { molecule } \mathrm{sec}^{-1} ; \\
\mathrm{H}+\mathrm{C}_{6} \mathrm{H}_{6} \longrightarrow \mathrm{C}_{6} \mathrm{H}_{7}, & \mathrm{k}=9.5 \times 10^{-14} \mathrm{~cm}^{3} \text { molecule-1 } \mathrm{sec}^{-1} ; \\
\mathrm{H}+\mathrm{CH}_{3}+\mathrm{He} \longrightarrow \mathrm{CH}_{4}+\mathrm{He}, & k=1.5 \times 10^{-29} \mathrm{~cm}^{6} \text { molecule-2 } \mathrm{sec}^{-1} ; \\
\mathrm{H}+\mathrm{C}_{2} \mathrm{H}_{5} \longrightarrow 2 \mathrm{CH}_{3}, & \mathrm{k}=6 \times 10^{-11} \mathrm{cmll}^{3} \text { molecule } \mathrm{sec}^{-1} .
\end{array}
$$

Ammonia, hydrogen sulfide, and formic acid can also be considered as possible hydrogenatom scavengers. They operate by the reactions:

$$
\begin{array}{ll}
\mathrm{H}+\mathrm{NH}_{3} \longrightarrow \mathrm{H}_{2}+\mathrm{NH}_{2}, & \mathrm{k}<10^{-16} \mathrm{~cm}^{3} \text { molecule }{ }^{-1} \mathrm{sec}^{-1} ; \\
\mathrm{H}+\mathrm{H}_{2} \mathrm{~S} \longrightarrow \mathrm{H}_{2}+\mathrm{HS}, & \mathrm{k}=8.4 \times 10^{-13} \mathrm{~cm}^{3} \text { molecule }{ }^{-1} \mathrm{sec}^{-1} ; \\
\mathrm{H}+\mathrm{H}_{2} \mathrm{CO} \longrightarrow \mathrm{H}_{2}+\mathrm{HCO}, & \mathrm{k}=3.9 \times 10^{-14} \mathrm{~cm}^{3} \text { molecule }{ }^{-1} \mathrm{sec}^{-1} .
\end{array}
$$

For tritium mixtures in the presence of water vapor, the formation of $T$ and $O H$ radicals appears to be a very important process for the final formation of tritiated water. Therefore, an additive gas should be found that will remove both $T$ and $O H$ radicals before they react with other radicals. There are a number of such $T$ and $\mathrm{OH}$ radical scavengers which could be used. The problem is to choose the one that is less hazardous or forms products that are less hazardous than the HTO.

Hence, the problem of eliminating or reducing the conversion of tritium to tritiated water is reduced to one of finding an approximate $\mathrm{OH}$ and/or $\mathrm{H}$ scavenger for the given . tritium mixture. 


\section{REFERENCES}

1. L. M. Dorfman and B. A. Hemmer, J. Chem. Phys. 22, 1555 (1954).

2. J. Yang and L. H. Gevantman, J. Phys. Chem. 68, 3115 (1964).

3. G. J. Casaletto, L. H. Gevantman, and J. B. Nash, The Self-Radiation Oxidation of Tritium in Oxygen and Aix, USNRDL-TR-565, Naval Radiol. Def. Lab., San Francisco, 1962.

4. J. D. Eakins and W. P. Hutchinson, Tritium, ed. by A. A. Moghissi and M. W. Carter, p. 392, Messenger Graphics, Phoenix, 1973.

5. L. F. Belovodskii, V. K. Gaevoi, V. I. Grishmanovskii, and N. V. Nefedov, At. Energ. 38, 379 (1975).

6. (a) J. C. Bixel, B. W. Hartzell, and W. K. Park, "Experimental Determination of Reaction Rates of Water-Hydrogen Exchange of Tritium with Hydrophobic Catalysts," pp. 1-9 in Proceedings of the Fourteenth ERDA Air Cleaning Conference, CONF-760822, 1975.

(b) L. F. Belovodskii, V. K. Gaevoi, V. I. Grishmanovsk11, V. V. Andramanov, V. N. Demenyuk, and V. V. Migunov, At. Energ. 38, 217 (1975).

7. E. A. Evans, Iritium and its Compounds, J. Wiley and Sons, Inc., New York, 1974.

8. J. H. Futrell and T. 0. Tiernan, Fundomental Processes in Radiation Chemistry, p. 171, ed. by P. Ausloos Interscience, New York, 1968.

9. R. L. Platzman, Int. J. App 2. Radiat. Isot. 10, 116 (1967).

10. A. R. Anderson, Fundamental Processes in Radiation Chemistry, p. 281, Pd. hy P Ausloos, Interscience, New York, 1968.

11. E. J. Henley and E. R. Johnston, The Chemistry and Physics of High Enerqu Reactions. University Press, Washington, D.C., 1969.

12. (a) W. H. Beattie, Int. J. Chem. Kinet. 4, 463 (1972).

(b) S. C. Lind, Radiation Chemistry of Gases, Reinhold, New York, 1961.

13. M. M. Mueller, "A Calculation of the Beta Energy Absorbed by Tritiated Gases in Spherical Vessels," Los Alamos Scientific Laboratory Report, LAMS-2580, 0ct. 10, 1961.

14. J. W. T. Spinks and R. J. Woods, An Introduction to Radiation Chemistry, 1. Wiley and Sons, Inc., New York, 1964.

15. (a) E. E. Ferguson, At. Data Nucl. Data Tables. 12, 159 (1973).

(b) M. J. McEwen and L. F. Philips, Chemistry of the Atmosphere, p. 170, 1. Wiley and Sons, Inc., New York, 1975. 
16. W. Lindinger, F. C. Fehsenfeld, A. L. Schmeltekof, and E. E. Ferguson, J. Geophys. Res. 79, 4753 (1974).

17. J. P. Payzant, A. J. Cummingham, and P. Kebarle, J. Chem. Phys. 59, 5615 (1973).

18. L. G. Anderson, Rev. Geophys. Space Phys. 14, 151 (1976).

19. C. J. Howard, V. M. Bierbaum, H. W. Rundle, and F. Kaufman, J. Chem. Phys. 57, 3491 (1972).

20. J. A. Burt, J. L. Dunn, M. J. McEwan, M. M. Sutton, A. E. Rocke, and H. I. Schiff, J. Chem. Phys. 52, 6062 (1970).

21. M. J. Leu, M. A. Bondi, and R. J. Johnston, Phys. Rev. A7, 292 (1973).

22. A. V. Phelps, Can. J. Chem. 47, 1783 (1969).

23. J. K. Kim and W. T. Huntress, Jr., Int. J. Mass. Spectrom. Ion Phys. 16, 451 (1975).

24. (a) T. R. Govers, M. Gérard, and R. Marx, Chem. Phys. 15, 185 (1976).

(b) C. J. Howard, H. W. Rundle, and F. Kaufman, J. Chem. Phys. $\underline{53}, 3745$ (1970).

(c) A. Good, D. A. Durden, and P. Kebarle, J. Chem. Phys. 52, 222 (1970).

25. R. A. Back, J. Phys. Chem. 64, 124 (1960). 
THIS PAGE

\section{WAS INTENTIONALLY \\ LEFT BLANK}


ORNL/TM-6699

Dist. Category UC-20, -20 e

INTERNAL DISTRIBUTION

\author{
1. J. A. Auxier \\ 2. J. T. Bell \\ 3. H. M. Butler \\ 4-30. C. E. Easterly \\ 31. J. A. Horak \\ 32. S. V. Kaye \\ 33. 0. B. Morgan \\ 34. T. W. Oakes \\ 35. D. C. Parzyck \\ 36-50. P. Papagiannakopoulos \\ 51. J. E. Phillips
}


91. V. A. Moroni, Argonne National Laboratory, Argonne, IL 60439

92. D. S. Myers, Lawrence Livermore Laboratory, Livermore, CA 94550

93. R. V. Osborne, Biology and Health Physics Division, Chalk River Nuclear Laboratories, Chalk River, Ontario, Canada

94. H. W. Patterson, Lawrence Livermore Laboratory, Livermore, CA 94550

95. T. B. Rhinehammer, Mound Laboratory, Miamisburg, $\mathrm{OH} 45342$

96. F. R. Scott, Fusion Program, EPRI, Palo Alto, CA 94303

97. K. Sako, JAERI, Tokai, Japan

98. J. K. Soldat, Battelle Pacific Northwest Laboratories, Richland, WA 99352

99. H. J. Willenberg, Battelle Pacific Northwest Laboratories, Richland, WA 99352

100. R. W. Wood, Division of Biomedical and Environmental Research, DOE, Washington, DC 20545

101. M. E. Wrenn, New York University Medical Center, P.0. Box 483, Tuxedo, NY 10987

102. J. R. Young, Battel le Northwest Laboratories, Richland, WA 99352

103. Office of Assistant Manager, Energy Research and Development, DOE-ORO, Dak. Ridge, TN 37830

104-245. Given distribution as shown in TID-4500 under UC-20, Magnetic Fusion Energy and $U C-20 e$, Environment and Safety 